\title{
Fraud Firms and the Matching Principle: Evidence from Korea ${ }^{\#}$
}

\author{
Jooyeon Hong, ${ }^{a^{*}}$ and Wonsun Paek ${ }^{a}$

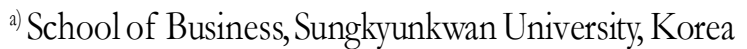

\begin{abstract}
This paper examines whether the degree of matching for poor-performing fraud firms varies depending on the strength of the causal relation between expenses and revenues. A stronger causal relation exists between revenues and operating expenses than between revenues and total expenses that include non-operating expenses as well as operating expenses. Fraud firms have stronger incentives for managing earnings. Given that managing earnings is easier when using non-operating items than when using operating items, the degree of matching is (not) lower for fraud firms than for non-fraud firms at the strong (weak) level of the causal relation between revenues and expenses. Empirical results suggest that the degrees of matching are different between fraud and non-fraud firms only at the strong level of the causal relation between revenues and expenses. This result implies that the investigation of the matching model at a strong level of the causal relation between revenues and expenses is more effective than that at a weak level of the causal relation, with regard to examining the degree of matching for fraud firms. This study contributes to the literature by providing evidence on the importance of the level of the causal relation when examining the degree of matching.
\end{abstract}

\begin{abstract}
Abstrak: Makalah ini membahas tentang apakah tingkat ketepatan untuk fraud firms berkinerja buruk bervariasi dan bergantung pada kekuatan hubungan kausal antara biaya dan pendapatan. Ada hubungan kausal yang lebih kuat antara pendapatan dan beban usaha dibandingkan dengan antara pendapatan dan yang biaya totalnya meliputi biaya nonoperasional serta biaya operasional. Frand firms memiliki dorongan kuat untuk mengelola labanya. Mengingat bahwa pengelolaan laba lebih mudah jika menggunakan item nonoperasional dibandingkan saat menggunakan item operasional, tingkat ketepatan/tidak tepat lebih rendah untuk fraud firms dibandingkan non-fraud firms yang kuat/lemah tingkat hubungan kausal antara pendapatan dan beban. Hasil empiris menunjukkan bahwa tingkat ketepatan yang berbeda antara fraud firms dan non-fraud firms hanya terjadi pada tingkat yang kuat dari hubungan kausal antara pendapatan dan beban. Hasil ini menunjukkan bahwa investigasi dari model kausal ketepatan pada tingkat yang kuat dari hubungan kausal antara pendapatan dan beban lebih efektif daripada penelitian pada tingkat lemah dari hubungan kausal, yang berkaitan dengan meneliti tingkat ketepatan untuk fraud firms. Penelitian ini memberikan kontribusi literatur dengan memberikan bukti tentang pentingnya tingkat hubungan kausal ketika meneliti tingkat ketepatan.
\end{abstract}

Keywords: causal relationship; fraud firms; matching

\# We appreciate the help ful comments from workshop participants at the International Joint Conference on Asia-Pacific Business Research at Universitas Gadjah Mada.

* Corresponding author's e-mail: jooyhong@skku.edu 


\section{Introduction}

This paper examines whether the degree of matching for fraud firms varies, depending on the strength of the causal relationship between expenses and revenues. It is known that fraud firms manipulate special items more frequently than operating items (Albrecht et al. 2008; Beneish 1999; Choi and Paek 1998). When we examine the degree of the matching between revenues and expenses for fraud firms, it is more effective to consider the level of the causal relation between revenues and expenses.

In general, the matching is stronger between sales and operating expenses or costs of goods sold than it is between revenues and total expenses. That is, to the extent that the matching with a strong causal relation is effective to that with a weak causal relation, the degree of the matching for fraud firms should be examined by considering the strength of the causal relation.

We focus on the different degree of the matching for fraud vis-à-vis non-fraud firms. Fraud firms have incentives to hide their poor performance by manipulating non-operating items (e.g., special items). As a result, the degree of the matching for fraud firms will differ from that for non-fraud firms depending on the level of a causal relation with expenses and revenues. In particular, at a weak level of the causal relation (such as revenues and total expenses), it is less likely that the degrees of the matching differ between fraud and non-fraud firms while at a strong level of the causal relation (such as revenues and operating expense or cost of goods sold), it is more likely to identify a difference of the degree of the matching between fraud and non-fraud firms. This study aims to provide evidence that the matching of expenses with revenues is distinguishable, depending on the strength of the causal relation between expenses and revenues.

The sample consists of 166 fraud firmyears and 6,467 non-fraud firm-years in nonbanking industries that are traded over the Korea Exchange from 1997 to 2009. The fraud firms consist of firms against which enforcement actions are taken by the Korea Financial Supervisory Service. We document that the degree of the matching for fraud firms is (not) different from that for non-fraud firms when there is a strong (weak) level of the causal relation between revenues and expenses. Therefore, the matching at the level of the strong causal relation is more effective than that at the level of the weak causal relation when we compare the different degrees of the matching between fraud and nonfraud firms.

This study is different from prior studies in that we consider the causal relation between expenses and revenues in examining the matching. The examination of an overall matching between total revenues and total expenses is not helpful in distinguishing the degree of the matching between fraud and non-fraud firms.

The remainder of the paper is organized as follows. Section 2 discusses the prior literature and develops the hypothesis. Section 3 describes the sample selection and research design. Section 4 presents the empirical results, and Section 5 concludes.

\section{Prior Literature and Hypothesis}

In Korea, the Financial Supervisory Service (FSS), a Korean SEC, reviews audit reports on a regular basis. It is generally rec- 
ognized that such a review contributes to the improvement of the overall accounting quality. The FSS selects "suspect firms" based on their financial ratios, discretionary accruals, and other financial data; it also reviews financial statements of suspect firms. The FSS also enforces penalties on firms, managers, and auditors per the review results.

The matching principle, which is a key concept in determining net income under the accrual basis together with the revenue recognition principle, requires that expenses incurred should be charged in the same period in which the corresponding revenues are earned. The Framework for the Preparation and Presentation of Financial Statements by the Intemational Accounting Standards Board states the following:

"Expenses are recognized in the income statement on the basis of a direct association between the costs incurred and the earning of specific items of income. This process, commonly referred to as the matching of costs with revenues, involves the simultaneous or combined recognition of revenues and expenses that result directly and jointly from the same transactions or other events; for example, the various components of expense making up the cost of goods sold are recognized at the same time as the income derived from the sale of the goods. However, the application of the matching concept under this Framework does not allow the recognition of items in the balance sheet which do not meet the definition of assets or liabilities" (para. 95).

When applying the matching principle, we face a serious problem of how to identify a causal relation between expenses and corresponding revenues. Most expenses, except for costs of goods sold and some other operating expenses, cannot be linked directly to revenues; hence, they are recorded during the period in which cash is paid or liabilities are recognized. For non-current assets whose benefits are expected over several periods, the expenses should be systematically allocated over those periods. When assets are impaired, the expenses should be recognized immediately. It is evident that these items do not fit in the framework of the traditional matching principle. Consequently, they cause a deterioration of proper matching and more importantly, the degree of the matching varies depending on the nature of expenses in relation to revenues.

One stream of prior research documents that the matching between expenses and revenues has deteriorated over time (Dichev and Tang 2008; Donelson et al. 2011; Paek 2011a; Collins et al. 1997; Francis and Schipper 1999). Dichev and Tang (2008) present a trend of the matching between expenses and revenues over the last 40 years and reveal that the degree of matching has been decreasing. They also observe that earnings volatility increases and earnings persistence decreases over the same period. Paek (2011a) observes a similar trend in Korea. These studies have identified special items reflecting economic events, losses, depreciation and discretionary accruals as primary causes for the decreasing pattern of the matching (Donelson et al. 2011; Paek 2011a). It is also documented that proper-matching firms have higher earnings qualities than poor-matching firms; moreover, the degree of matching varies systematically depending on a firm's lifecycle stages (Paek 2011b; Paek and Park 2013; Park and Paek 2013).

Another stream of prior research documents that special items are often used by fraud firms in order to manipulate earnings (Albrecht et al. 2008; Marguardf and Wiedman 2004; McVay 2006; Fan et al. 2010; 
Brazel et al. 2009). When a firm shifts operating expenses into special items so as to hide its poor operating performance, the matching between revenues and total expenses is not likely to be affected; rather, the matching between revenues and operating expenses will be affected. This suggests that a different pattern of the matching between fraud and non-fraud firms can be identified at the level of the causal relation between revenues and specific categories of expenses.

Note that fraud firms manipulate earnings through more non-operating items (e.g., special items) than operating items (Marquardt and Wiedman 2004; Elliott and Hanna 1996). This leads us to believe that the degree of the matching above operating income (i.e., revenues and operating expenses) will be different from below operating income (i.e., revenues and total expenses) between fraud and non-fraud firms. Thus, our hypothesis is as follows:

$H$ : The revenue-expense matching is (not) less proper for frand firms than for non-frand firms at the strong (weak) level of causal relation between revenues and expenses.

\section{Sample Selection and Research Design}

\section{Sample selection}

The initial sample is identified from the KIS-VALUE database. The sample is restricted to firm-years in order to include complete data for all variables in the empirical analysis. In order to synchronize the period of the fraud firms, the sample periods starts in 1997 and ends in 2009. To enhance homogeneity of the sample, only non-banking firms are included. To mitigate the influence of extreme observations, we delete the top and bottom 1 percent of all variables. The final sample consists of 6,633 firm-year observations from 1997 to 2009. Fraud firms are firms against which enforcement actions are taken by the Korean Financial Supervisory Service. The final numbers of non-fraud and fraud firm-years are 6,467 and 166, respectively. Table 1 summarizes the sample selection procedure.

\section{Table 1. Sample Selection}

\section{Sample Selection Criteria}

Firm-years

Initial sample traded over the Korea Exchange for 1997-2009 with

December fiscal year end and operating in non-banking industries

Firm-years with missing values for all variables

Firm-years outside the most extreme 1 percentiles

Final sample

Fraud sample that is enforced by the Korean Financial Supervisory Service for 1997-2009

Non-fraud sample 


\section{Research Models}

We adopt Dichev and Tang's (2008) model, which regresses the current-period revenues on previous-period, current-period, and next-period expenses. In this model, a large coefficient on current-period expenses implies proper matching between contemporaneous revenues and expenses. We use the following three versions of Dichev and Tang model: (i) total expenses and total revenues, (ii) operating expenses and net sales, and (iii) cost of goods sold and net sales.

$$
\begin{aligned}
& \operatorname{REV}_{\mathrm{t}}=\alpha_{0}+\alpha_{1} \mathrm{EXP}_{\mathrm{t}-1}+\alpha_{2} \mathrm{EXP}_{\mathrm{t}}+ \\
& \alpha_{3} \operatorname{EXP}_{\mathrm{t}+1}+\varepsilon_{\mathrm{t}} \\
& \text { Sales }_{\mathrm{t}}=\beta_{0}+\beta_{1} \text { OPEREXP }_{\mathrm{t}-1}+ \\
& \beta_{2} \text { OPEREXP }_{\mathrm{t}}+ \\
& \beta_{3} \text { OPEREXP }_{t+1}+v_{t} \\
& \text { Sales }_{\mathrm{t}}=\delta_{0}+\delta_{1} \text { COGS }_{\mathrm{t}-1}+\delta_{2} \text { COGS }_{\mathrm{t}}+ \\
& \delta_{3} \mathrm{COGS}_{\mathrm{t}+1}+v_{\mathrm{t}}
\end{aligned}
$$

where $R E V_{t}$ is total revenues for year $t$, calculated as the sum of sales and non-operating income, EXP is total expenses for year $t$, calculated as the difference between revenues and net income for year $t$, Sales is net sales for year $t, O P E R E X P_{t}$ is operating expenses for year $\mathrm{t}$, calculated as the difference between sales and operating income, COGS is cost of goods sold for year $t$, all are deflated by average assets.

We consider Equation (1) as a weak causal relation, and Equations (2) and (3) as strong causal relations.

To test the hypothesis, we modify Models (1)-(3) by adding an indicator variable for fraud firms (Frand) and its interaction with expenses. Thus, we estimate the following models:

$$
\begin{aligned}
\operatorname{REV}_{\mathrm{t}}= & \alpha_{10}+\alpha_{11} \text { Fraud }_{\mathrm{t}}+\alpha_{12} \operatorname{EXP}_{\mathrm{t}-1}+ \\
& \alpha_{13} \operatorname{EXP}_{\mathrm{t}}+\alpha_{14} \operatorname{EXP}_{\mathrm{t}+1}+ \\
& \alpha_{15} \operatorname{Fraud}_{\mathrm{t}}^{*} \mathrm{EXP}_{\mathrm{t}-1}+ \\
& \alpha_{16} \operatorname{Fraud}_{\mathrm{t}}^{*} \mathrm{EXP}_{\mathrm{t}}+ \\
& \alpha_{17} \text { Fraud }_{\mathrm{t}}^{*} \mathrm{EXP}_{\mathrm{t}+1}+\varepsilon_{\mathrm{t}} \ldots \ldots \ldots . . .(4)
\end{aligned}
$$

$$
\begin{aligned}
& \text { Sales }_{\mathrm{t}}=\boldsymbol{\beta}_{10}+\boldsymbol{\beta}_{11} \text { Fraud }_{\mathrm{t}}+ \\
& \beta_{12} \text { OPEREXP }_{\mathrm{t}-1}+ \\
& \beta_{13} \text { OPEREXP }_{t}+ \\
& \beta_{14} \text { OPEREXP }_{\mathrm{t}+1}+ \\
& \beta_{15} \text { Fraud }_{\mathrm{t}}^{*} \text { OPEREXP }{ }_{\mathrm{t}-1}+ \\
& \beta_{16} \text { Fraud }_{t}^{*} \text { OPEREXP }+ \\
& \beta_{17} \text { Fraud }_{\mathrm{t}}^{*} \text { OPEREXP }{ }_{\mathrm{t}+1}+ \\
& u_{t} \text {. }
\end{aligned}
$$

$$
\begin{aligned}
& \text { Sales }_{\mathrm{t}}=\delta_{10}+\delta_{11} \text { Fraud }_{\mathrm{t}}+\delta_{12} \text { COGS }_{\mathrm{t}-1}+ \\
& \delta_{13} \mathrm{COGS}_{\mathrm{t}}+\delta_{14} \mathrm{COGS}_{\mathrm{t}+1}+ \\
& \delta_{15} \text { Fraud }_{\mathrm{t}} * \mathrm{COGS}_{\mathrm{t}-1}+ \\
& \delta_{16} \text { Fraud }_{t}^{*} \text { COGS }_{t}+ \\
& \delta_{17} \operatorname{Fraud}_{\mathrm{t}}^{*} \mathrm{COGS}_{\mathrm{t}+1}+ \\
& v_{\mathrm{t}}
\end{aligned}
$$

where Frand is 1 if a firm-year is enforced by the Korean Financial Supervisory Service in year $t$, and 0 otherwise; all other variables are as defined in the below Equation (3).

If the matching is indistinguishable between fraud and non-fraud firms at the weak level of the causal relation, we predict the coefficients on Fraud ${ }_{t}^{*} \operatorname{EXP}_{t}\left(\alpha_{16}\right)$ to be insignificantly different from zero. On the other hand, if the matching becomes less proper for fraud firms than non-fraud firms at the strong level of the causal relation, we predict the coefficients on Frand ${ }_{t}^{*} O P E R E X P$, $\left(\alpha_{16}\right)$ or Fraud ${ }_{t}^{*}$ COGS $\left(\delta_{16}\right)$ to be negative. 


\section{Results}

\section{Descriptive Statistics and Correlation}

Descriptive statistics for the main variables are presented in Table 2. For non-fraud firm years in panel $A$, the mean and median of total revenue $(R E V)$ are 100.3 percent and 93.7 percent of the average total assets, respectively. The mean and median of net sales (Sales) are 94.8 percent and 88.5 percent of the average total assets, respectively. The mean (median) of total expenses (EXP) is 99.2 percent $(92.3 \%)$ of the average total assets, and the mean (median) of operating expenses (OPEREXP) is 90.3 percent $(83.3 \%)$ of the average total assets. The mean (median) of cost of goods sold $(C O G S)$ is 78.0 percent $(71.7 \%)$ of the average total as sets.

For fraud firm years in Panel B, the fraud firm-years' mean (median) of EXP, OPEREXP , and COGS are, respectively, 88.3 percent $(79.8 \%), 75.6$ percent $(68.5 \%)$, and 65.0 percent $(58.4 \%)$ of the average total assets. It is not unusual that fraud firms show poorer performance than non-fraud firms in almost every aspect (Kirkos et al. 2007, Persons 1995, Choi and Choe 2003).

Table 3 shows the correlation among the main variables. Pearson correlations are below the diagonal and Spearman correlations are above the diagonal. Spearman correlation between total revenues $(R E V)$ and total ex- penses $\left(E X P_{t}\right)$ is 0.958 , whereas the correlation between net sales (Sales) and total expenses $\left(E X P_{t}\right)$, operating expenses (OPEREXP ), and cost of goods sold $\left(C O G S_{t}\right)$ is $0.950,0.982$, and 0.934 , respectively. Not surprisingly, the correlation between net sales and operating expenses is larger than the correlation between net sales and total expenses. However, the correlation between net sales and cost of goods sold is smaller than that between net sales and operating expenses or total expenses.

\section{Trend of the Matching between Revenues and Expenses}

In Table 4, we report the results of the trend of the matching. Panel A of Table 4 presents the trend of the matching between revenues and expenses over the sample period. The coefficients on EXP in Equation (1) show a slightly increasing trend over time. However, the coefficients on OPEREXP and $C O G S_{t}$ in Equations (2) and (3) do not show a noticeable trend over time. Mean (median) coefficients on EXP, OPEREXP and COGS are $0.974,1.035$, and 1.083 , respectively. The result indicates that the means of the three coefficients are significantly different from each other in the decreasing order of COGS, OPEREXP and EXP. This implies that the relation between sales and cost of goods sold is the strongest, whereas the relation between total revenues and total expenses is weaker than the relation between sales and other expenses. 
Table 2. Descriptive Statistics

Panel A: Non-fraud sample

\begin{tabular}{lcccccc} 
Variables & N & Mean & Std Dev. & Median & Min & Max \\
\hline REVt & 6,467 & 1.003 & 0.435 & 0.937 & 0.138 & 3.269 \\
Salest & 6,467 & 0.948 & 0.431 & 0.885 & 0.097 & 3.088 \\
EXPt & 6,467 & 0.992 & 0.419 & 0.923 & 0.175 & 3.203 \\
OPEREXPt & 6,467 & 0.903 & 0.414 & 0.833 & 0.124 & 3.020 \\
COGSt & 6,467 & 0.780 & 0.398 & 0.717 & 0.049 & 2.854 \\
Et & 6,467 & 0.010 & 0.103 & 0.025 & -0.687 & 0.280
\end{tabular}

Panel B: Fraud sample

\begin{tabular}{lcccccc} 
Variables & N & Mean & Std Dev. & Median & Min & Max \\
\hline REVt & 166 & 0.837 & 0.366 & 0.760 & 0.215 & 2.543 \\
Salest & 166 & 0.778 & 0.372 & 0.711 & 0.173 & 2.480 \\
EXPt & 166 & 0.883 & 0.352 & 0.798 & 0.367 & 2.615 \\
OPEREXPt & 166 & 0.756 & 0.356 & 0.685 & 0.263 & 2.455 \\
COGSt & 166 & 0.650 & 0.351 & 0.584 & 0.091 & 2.339 \\
Et & 166 & -0.046 & 0.139 & 0.003 & -0.645 & 0.111 \\
\hline
\end{tabular}

This table reports descriptive statistics for non-fraud and fraud samples.

\section{Variable definitions:}

$R E V_{t}$ is total revenues for year $\mathrm{t}$, calculated as the sum of sales and non-operating income, EXP is total expenses for year $t$, calculated as the difference between revenues and net income for year $t$, Sales is net sales for year $t$, OPEREXP is operating expenses for year $t$, calculated as the difference between sales and operating income, COGS is cost of goods sold for year $t, E_{t}$ is net income for year $t$, and all deflated by average assets.

Table 3. Correlations

\begin{tabular}{lcccccc}
\hline Variables & $\mathbf{R E V}_{\mathbf{t}}$ & Sales $_{\mathbf{t}}$ & $\mathbf{E X P}_{\mathbf{t}}$ & OPEREXP $_{\mathbf{t}}$ & COGS $_{\mathbf{t}}$ & $\mathbf{E}_{\mathbf{t}}$ \\
\hline REV $_{t}$ & & $0.989^{* * * *}$ & $0.958^{* * *}$ & $0.976^{* * *}$ & $0.931 * * *$ & $0.337^{* * *}$ \\
Sales $_{t}$ & $0.992^{* * *}$ & & $0.950^{* * * *}$ & $0.982^{* * *}$ & $0.934 * * *$ & $0.318^{* * *}$ \\
EXP $_{t}$ & $0.971^{* * *}$ & $0.965^{* * * *}$ & & $0.975^{* * *}$ & $0.930^{* * *}$ & $0.130^{* * *}$ \\
OPEREXP $_{t}$ & $0.983^{* * *}$ & $0.987^{* * *}$ & $0.983^{* * * *}$ & & $0.956 * * *$ & $0.211 * * *$ \\
COGS $_{t}$ & $0.953^{* * *}$ & $0.956^{* * *}$ & $0.953^{* * *}$ & $0.970^{* * *}$ & & $0.178^{* * *}$ \\
$E_{t}$ & $0.274 * * *$ & $0.265^{* * *}$ & $0.037 * * *$ & $0.156 * * *$ & $0.153 * * *$ & \\
\hline
\end{tabular}

This table reports Pearson (Spearman) correlation below (above) the diagonal.

Two-tailed t-test, ${ }^{* * *}$ indicate significance at the 1 percent levels.

See Table 2 for variable definitions. 


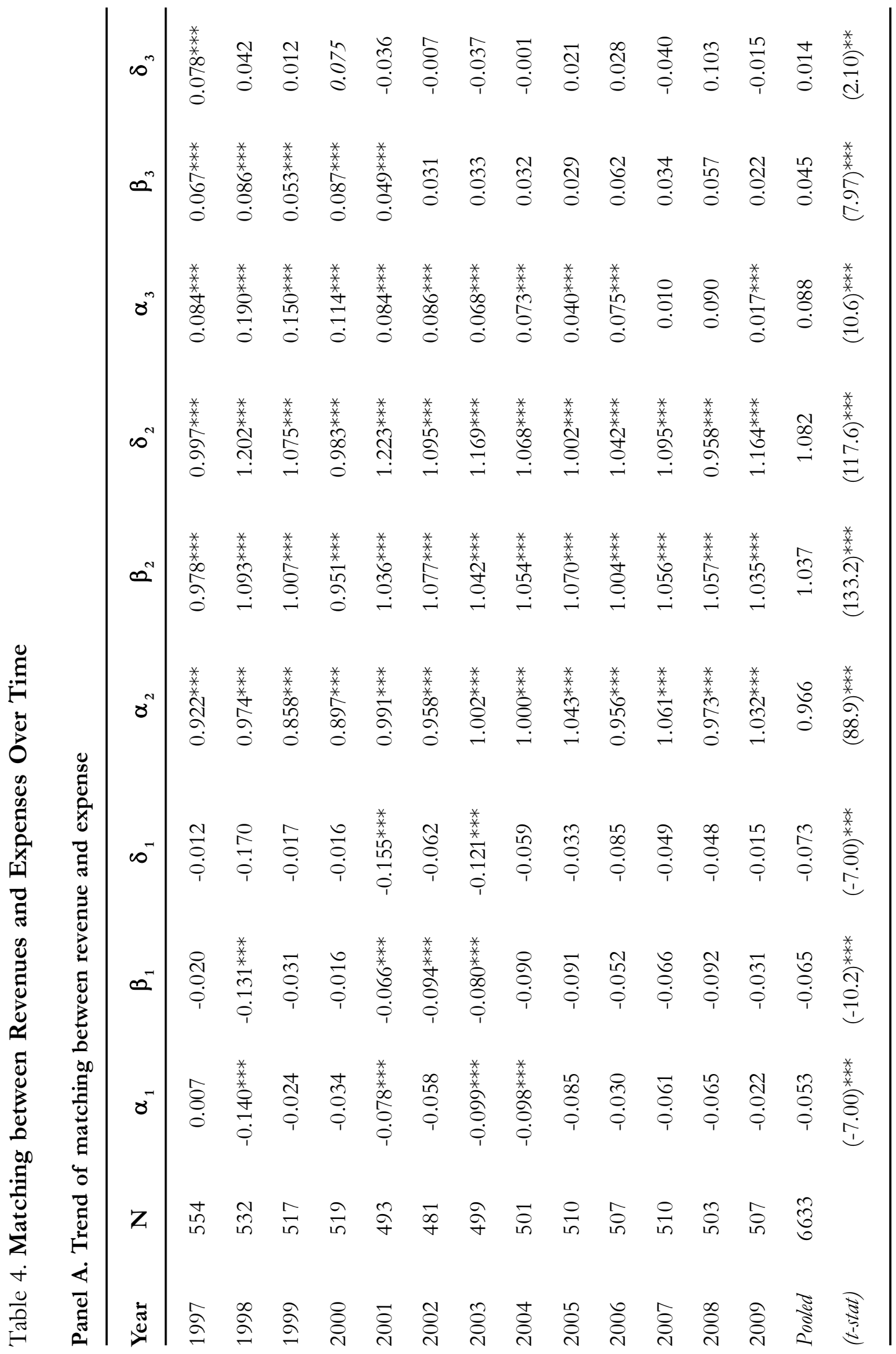




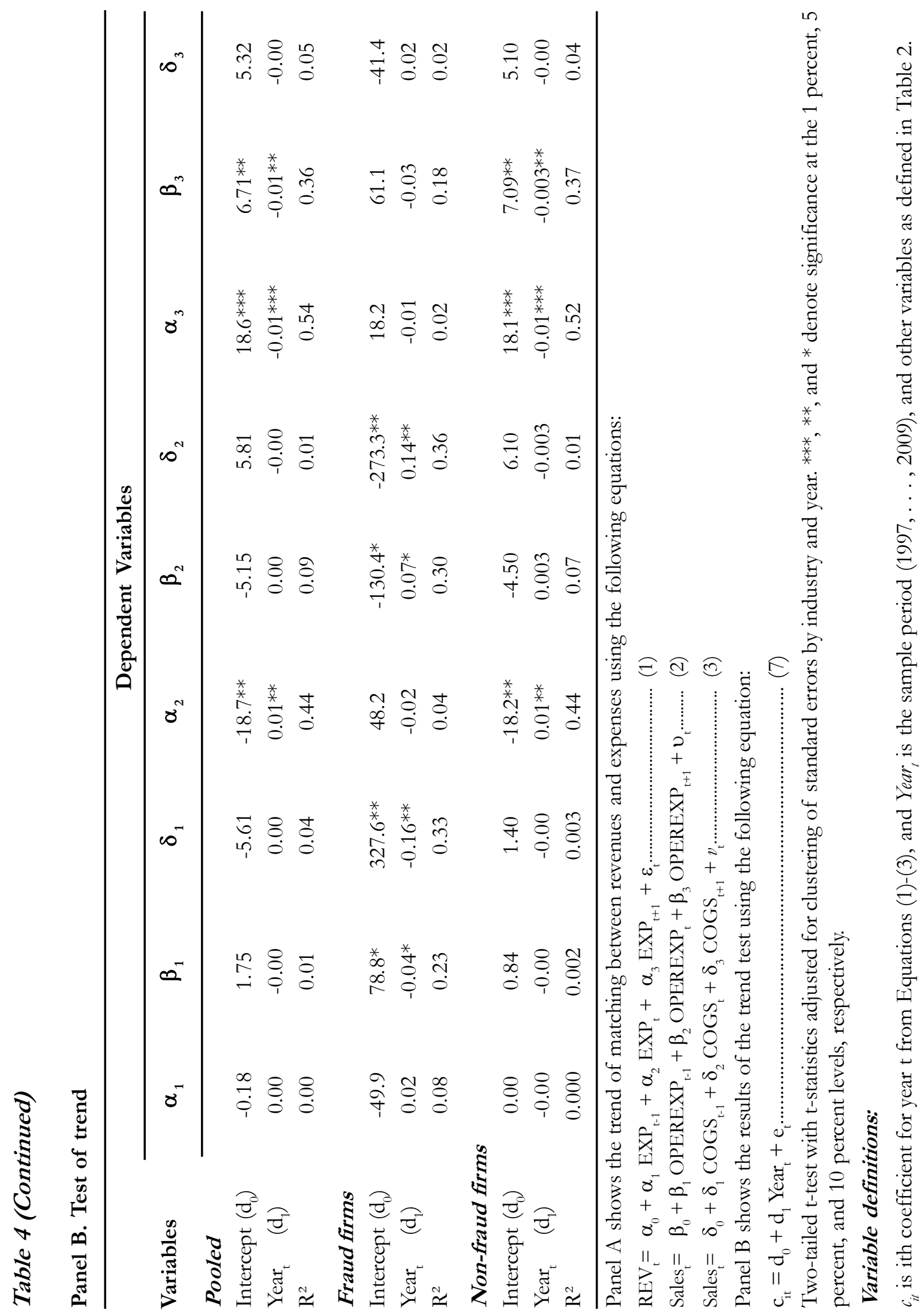


Panel B in Table 4 shows the results of the following regression in which the coefficient estimates from Equations (1)-(3) are regressed on the sample period (Year):

$$
c_{i t}=d_{0}+d_{1} \text { Year }_{t}+e_{i t}
$$

where $c_{i t}$ is the ith coefficient for year t from Equations (1)-(3), and Year is the sample pe$\operatorname{riod}(1997, \ldots, 2009)$.

In Equation (7), a positive (negative) coefficient on Year indicates an increasing (decreasing) trend of the degree of the matching between sales and expenses.

Panel B in Table 4 presents that the trend of the matching for the pooled sample is dominated by the non-fraud sample. Also, the contemporaneous matching between revenue and total expenses $\left(\alpha_{2}\right)$ is significantly positive only for the non-fraud sample, implying that for the non-fraud sample, the matching between revenues and total expenses is enhanced over time; yet, the contemporaneous matching between sales and operating expenses or cost of goods sold $\left(\beta_{2}\right.$, $\delta_{2}$ ) is significantly positive only for the fraud sample, showing that for the fraud sample, the matching between revenues and operating expenses or cost of goods sold is improved over time. Further, the lagged matching $\left(\beta_{1}\right.$, $\delta_{1}$ ) shows a more decreasing trend for the fraud sample than the non-fraud sample. The lead matching $\left(\alpha_{3}, \beta_{3}, \delta_{3}\right)$ does not show a noticeable difference in the trend between fraud and non-fraud samples.

Though not consistent with prior studies, this suggests that there's a difference of the matching patterns between fraud and nonfraud samples. The inconsistent evidence on the enhanced contemporaneous matching between revenues and total expenses might result from a shorter sample period in this study compared to prior studies. Further, firms experience several economic crises during this period so that the trend of the matching reported in Table 4 might not be typical.

\section{The Matching between Revenues and Expenses for Fraud and Non-fraud Firms}

Table 5 presents the regression results of estimating Equations (4)-(6). We investigate whether the degree of the matching for fraud firms is different from the degree of matching for non-fraud firms.

In panel $A$, we present the result of the matching between total expenses and total revenues. The coefficient on current-period total expenses $(E X P)$ for non-fraud firms is significantly positive $(0.967)$. The incremental coefficient on current-period total expense for fraud firms is insignificantly different from zero. This result suggests that the degree of the matching between total expenses and total revenues for fraud firms is not different from that for non-fraud firms at the weak level of the causal relationship.

Panel B presents the result of the matching between operating expenses and net sales. The coefficient on current-period operating expenses (OPEREXP) is significantly positive (1.038), while the incremental coefficient on operating expenses for fraud firms is insignificant. This suggests that the matching of fraud firms is again not different from that of the non-fraud firms at the level of operating expenses.

Panel $\mathrm{C}$ is the result of the matching between cost of goods sold and net sales. The incremental coefficient on current-period cost of goods sold (COGS) is -0.210 , therefore significantly negative. This indicates that the matching degree is less proper for fraud firms 
than for non-fraud firms. Overall, the result in Table 5 provides evidence that the level of the causal relation between revenues and expenses affects the revenue-expense matching between fraud firms and normal firms.

Table 5. Matching between Revenues and Expenses

Panel A. Matching between total revenues and total expenses

\begin{tabular}{lllr}
\hline Variables & & Coeffs. & t Value \\
\hline Intercept & $\left(\alpha_{10}\right)$ & 0.001 & 0.31 \\
Fraud $_{t}$ & $\left(\alpha_{11}\right)$ & -0.016 & -0.63 \\
$\operatorname{EXP}_{\mathrm{t}-1}$ & $\left(\alpha_{12}\right)$ & $-0.055^{* * *}$ & -7.06 \\
$\mathrm{EXP}_{\mathrm{t}}$ & $\left(\alpha_{13}\right)$ & $0.967 * * *$ & 89.44 \\
$\mathrm{EXP}_{\mathrm{t}+1}$ & $\left(\alpha_{14}\right)$ & $0.088 * * *$ & 10.68 \\
Fraud $_{\mathrm{t}} \mathrm{EXP}_{\mathrm{t}-1}$ & $\left(\alpha_{15}\right)$ & 0.034 & 0.82 \\
Fraud $_{\mathrm{t}}^{*} \mathrm{EXP}_{\mathrm{t}}$ & $\left(\alpha_{10}\right)$ & -0.047 & -0.65 \\
Fraud $_{\mathrm{t}}^{*} \mathrm{EXP}_{\mathrm{t}+1}$ & $\left(\alpha_{17}\right)$ & -0.029 & -0.46 \\
Adjusted R $^{2}$ & & 0.947 &
\end{tabular}

Panel B. Matching between sales and operating expenses

$\begin{array}{llcr}\text { Intercept } & \left(\beta_{10}\right) & 0.025 * * * & 6.40 \\ \text { Fraud }_{\mathrm{t}} & \left(\beta_{11}\right) & -0.015 & -1.02 \\ \text { OPEREXP }_{\mathrm{t}-1} & \left(\beta_{12}\right) & -0.066 * * * & -10.02 \\ \text { OPEREXP }_{\mathrm{t}} & \left(\beta_{13}\right) & 1.038^{* * *} & 132.12 \\ \text { OPEREXP }_{\mathrm{t}+1} & \left(\beta_{14}\right) & 0.044^{* * *} & 7.72 \\ \text { Fraud }_{\mathrm{t}}^{*} \text { OPEREXP }_{\mathrm{t}-1} & \left(\beta_{15}\right) & 0.013 & 0.40 \\ \text { Fraud }_{\mathrm{t}} \text { OPPEREXP }_{\mathrm{t}} & \left(\beta_{16}\right) & -0.074 & -1.26 \\ \text { Fraud }_{\mathrm{t}}^{*} \text { OPEREXP }_{\mathrm{t}+1} & \left(\beta_{17}\right) & 0.058 & 1.26 \\ \text { Adjusted R }^{2} & & 0.975 & \end{array}$


Table 5 (Continued)

Panel C. Matching between sales and cost of goods sold

\begin{tabular}{lllc}
\hline Variables & & Coeffs. & t Value \\
\hline Intercept & $\left(\delta_{10}\right)$ & $0.147^{* * *}$ & 13.46 \\
Fraud $_{\mathrm{t}}$ & $\left(\delta_{11}\right)$ & -0.026 & -1.06 \\
COGS $_{\mathrm{t}-1}$ & $\left(\delta_{12}\right)$ & $-0.074 * * *$ & -7.04 \\
COGS $_{\mathrm{t}}$ & $\left(\delta_{13}\right)$ & $1.085^{* * *}$ & 116.50 \\
COGS $_{\mathrm{t}+1}$ & $\left(\delta_{14}\right)$ & $0.012^{*}$ & 1.78 \\
Fraud $_{\mathrm{t}}^{*}$ COGS $_{\mathrm{t}-1}$ & $\left(\delta_{15}\right)$ & $0.070^{*}$ & 1.75 \\
Fraud $_{\mathrm{t}}^{*}$ COGS $_{\mathrm{t}}$ & $\left(\delta_{10}\right)$ & $-0.210^{* * *}$ & -3.12 \\
Fraud $_{\mathrm{t}}^{*}$ COGS $_{\mathrm{t}+1}$ & $\left(\delta_{17}\right)$ & $0.129 * *$ & 2.36 \\
Adjusted R $^{2}$ & & 0.915 & \\
\hline
\end{tabular}

Panel A presents the different matching between revenues and total expenses for the fraud and non-fraud samples using the following equation:

$$
\begin{aligned}
& \operatorname{REV}_{\mathrm{t}}=\alpha_{10}+\alpha_{11} \operatorname{Fraud}_{\mathrm{t}}+\alpha_{12} \operatorname{EXP}_{\mathrm{t}-1}+\alpha_{13} \operatorname{EXP}_{\mathrm{t}}+\alpha_{14} \operatorname{EXP}_{\mathrm{t}+1}+\alpha_{15} \operatorname{Fraud}_{\mathrm{t}}^{*} \mathrm{EXP}_{\mathrm{t}-1}+ \\
& \alpha_{16} \operatorname{Fraud}_{\mathrm{t}} * \mathrm{EXP}_{\mathrm{t}}+\alpha_{17} \operatorname{Fraud}_{\mathrm{t}}{ }^{\mathrm{EXP}} \mathrm{EX}_{\mathrm{t}+1}+\varepsilon_{\mathrm{t}}
\end{aligned}
$$

Panel B presents the different matching between revenues and operating expenses for the fraud and nonfraud samples using the following equation:

$$
\begin{aligned}
& \text { Sales }_{\mathrm{t}}=\beta_{10}+\beta_{11} \text { Fraud }_{\mathrm{t}}+\beta_{12} \text { OPEREXP }_{\mathrm{t}-1}+\beta_{13} \text { OPEREXP }_{\mathrm{t}}+\beta_{14} \text { OPEREXP }_{\mathrm{t}+1}+ \\
& \beta_{15} \text { Fraud }_{t}^{*} \operatorname{OPEREXP}_{\mathrm{t}-1}+\beta_{16} \text { Fraud }_{\mathrm{t}}^{*} \text { OPEREXP }_{\mathrm{t}}+\beta_{17} \text { Fraud }_{\mathrm{t}}^{*} \operatorname{OPEREXP}_{\mathrm{t}+1}+ \\
& u_{t}
\end{aligned}
$$

And Panel C presents the different matching between revenues and cost of goods sold for the fraud and non-fraud samples using the following equation:

$$
\begin{aligned}
& \text { Sales }_{\mathrm{t}}=\delta_{10}+\delta_{11} \text { Fraud }_{\mathrm{t}}+\delta_{12} \text { COGS }_{\mathrm{t}-1}+\delta_{13} \text { COGS }_{\mathrm{t}}+\delta_{14} \text { COGS }_{\mathrm{t}+1}+\delta_{15} \text { Fraud }_{\mathrm{t}} * \operatorname{COGS}_{\mathrm{t}-1}+ \\
& \delta_{16} \operatorname{Fraud}_{\mathrm{t}}^{*} \mathrm{COGS}_{\mathrm{t}}+\delta_{17} \operatorname{Fraud}_{\mathrm{t}}^{*} \mathrm{COGS}_{\mathrm{t}+1}+v_{\mathrm{t}}
\end{aligned}
$$

Two-tailed $\mathrm{t}$-test with $\mathrm{t}$-statistics adjusted for clustering of standard errors by industry and year. ***, **, and ${ }^{*}$ denote significance at the 1 percent, 5 percent, and 10 percent levels, respectively.

\section{Variable definitions:}

Fraud $_{t}$ is 1 if a firm-year is enforced by Korean Financial Supervisory Service in year t, and 0 otherwise, and other variables as defined in Table 2. 
Prior literature documents that loss firms show different characteristics from profit firms (Hayn 1995; Altman 1968). As a robustness check, we re-perform the analysis after excluding loss firms and present the results in Table 6. Panel A shows the results of the matching of total cost with total revenue for profit samples. The coefficient of fraud firms' current-period expenses is insignificantly different from the coefficient of non-fraud firms' current-period expenses, consistent with the results in Table 5.

Panel B presents the result of the matching between net sales and operating expenses. The incremental coefficient on fraud firms' current-period operating expenses is significantly negative (-0.110), suggesting that the degree of the matching is lower for fraud firms than for non-fraud firms at the level of operating expenses.
Panel C shows the results of the matching between net sales and cost of goods sold. The incremental coefficient for fraud firms' current-period cost of goods sold is significantly negative, indicating that the matching is less proper for fraud firms than for nonfraud firms at the level of cost of goods sold.

In conclusion, when the causal relation between revenues and expenses is weak (i.e., total revenues and total expenses), it is difficult to distinguish the degree of the matching between fraud firms and non-fraud firms. However, when the causal relation between revenues and expenses is strong (i.e., net sales and cost of goods sold), we are able to effectively distinguish the degree of the matching between fraud and non-fraud firms.

Table 6. Matching between Total Revenues and Total Expenses, Excluding Loss Firms

Panel A. Matching between total revenues and total expenses

\begin{tabular}{llcc}
\hline Variables & & Coeffs. & t Value \\
\hline Intercept & $\left(\alpha_{10}\right)$ & $0.037 * * *$ & 12.95 \\
Fraud $_{t}$ & $\left(\alpha_{11}\right)$ & $-0.021 * *$ & -1.98 \\
$\mathrm{EXP}_{\mathrm{t}-1}$ & $\left(\alpha_{12}\right)$ & -0.006 & -1.25 \\
$\mathrm{EXP}_{\mathrm{t}}$ & $\left(\alpha_{13}\right)$ & $1.015 * * *$ & 200.26 \\
$\mathrm{EXP}_{\mathrm{t}+1}$ & $\left(\alpha_{11}\right)$ & 0.003 & 1.03 \\
Fraud $_{\mathrm{t}}^{*} \mathrm{EXP}_{\mathrm{t}-1}$ & $\left(\alpha_{15}\right)$ & 0.016 & 0.80 \\
Fraud $_{\mathrm{t}}^{*} \mathrm{EXP}_{\mathrm{t}}$ & $\left(\alpha_{10}\right)$ & -0.025 & -0.76 \\
Fraud $_{\mathrm{t}}^{*} \mathrm{EXP}_{\mathrm{t}+1}$ & $\left(\alpha_{17}\right)$ & 0.016 & 0.75 \\
Adjusted R $^{2}$ & & 0.991 &
\end{tabular}


Table 6 (Continued)

Panel B. Matching between sales and operating expenses

\begin{tabular}{lllr}
\hline Variables & & Coeffs. & t Value \\
\hline Intercept & $\left(\beta_{10}\right)$ & $0.051 * * *$ & 14.14 \\
Fraud $_{\mathrm{t}}$ & $\left(\beta_{11}\right)$ & -0.015 & -1.06 \\
OPEREXP $_{\mathrm{t}-1}$ & $\left(\beta_{12}\right)$ & $-0.044 * * *$ & -7.39 \\
OPEREXP $_{\mathrm{t}}$ & $\left(\beta_{13}\right)$ & $1.046 * * *$ & 161.57 \\
OPEREXP $_{\mathrm{t}+1}$ & $\left(\beta_{14}\right)$ & $0.011 * *$ & 2.56 \\
Fraud $_{\mathrm{t}}^{*}$ OPEREXP $_{\mathrm{t}-1}$ & $\left(\beta_{15}\right)$ & $0.063 * *$ & 2.59 \\
Fraud $_{\mathrm{t}}^{*}$ OPEREXP $_{\mathrm{t}}$ & $\left(\beta_{16}\right)$ & $-0.110^{* *}$ & -2.57 \\
Fraud $_{\mathrm{t}}^{*}$ OPEREXP $_{\mathrm{t}+1}$ & $\left(\beta_{17}\right)$ & $0.061 *$ & 1.92 \\
Adjusted R $^{2}$ & & 0.986 &
\end{tabular}

\section{Panel C. Matching between sales and cost of goods sold}

$\begin{array}{llcr}\text { Intercept } & \left(\delta_{10}\right) & 0.185 * * * & 14.73 \\ \text { Fraud }_{\mathrm{t}} & \left(\delta_{11}\right) & 0.001 & 0.02 \\ \text { COGS }_{\mathrm{t}-1} & \left(\delta_{12}\right) & -0.055^{* * *} & -4.42 \\ \text { COGS }_{\mathrm{t}} & \left(\delta_{13}\right) & 1.083 * * * & 105.34 \\ \text { COGS }_{\mathrm{t}+1} & \left(\delta_{14}\right) & -0.021 * * * & -2.72 \\ \text { Fraud }_{\mathrm{t}}^{*} \text { COGS }_{\mathrm{t}-1} & \left(\delta_{15}\right) & 0.027 & 0.43 \\ \text { Fraud }_{\mathrm{t}}^{*} \text { COGS }_{\mathrm{t}} & \left(\delta_{10}\right) & -0.209 * & -1.70 \\ \text { Fraud }_{\mathrm{t}}^{*} \text { COGS }_{\mathrm{t}+1} & \left(\delta_{17}\right) & 0.134 & 1.63 \\ \text { Adjusted R }^{2} & & 0.915 & \end{array}$

This table presents the different matching between revenues and expenses for the fraud and non-fraud samples, after excluding loss firms. Panel A presents the different matching between revenues and total expenses for the fraud and non-fraud samples using the following equation:

$$
\begin{aligned}
& \operatorname{REV}_{\mathrm{t}}=\alpha_{10}+\alpha_{11} \text { Fraud }_{\mathrm{t}}+\alpha_{12} \operatorname{EXP}_{\mathrm{t}-1}+\alpha_{13} \mathrm{EXP}_{\mathrm{t}}+\alpha_{14} \operatorname{EXP}_{\mathrm{t}+1}+\alpha_{15} \text { Fraud }_{\mathrm{t}} \operatorname{EXP}_{\mathrm{t}-1}+ \\
& \alpha_{16} \operatorname{Fraud}_{\mathrm{t}} * \mathrm{EXP}_{\mathrm{t}}+\alpha_{17} \text { Fraud }_{\mathrm{t}}^{*} \mathrm{EXP}_{\mathrm{t}+1}+\varepsilon_{\mathrm{t}}
\end{aligned}
$$

Panel B presents the different matching between revenues and operating expenses for the fraud and nonfraud samples using the following equation:

$$
\begin{aligned}
& \text { Sales }_{\mathrm{t}}=\beta_{10}+\beta_{11} \text { Fraud }_{\mathrm{t}}+\beta_{12} \text { OPEREXP }_{\mathrm{t}-1}+\beta_{13} \text { OPEREXP }_{\mathrm{t}}+\beta_{14} \text { OPEREXP }_{\mathrm{t}+1}+ \\
& \beta_{15} \text { Fraud }_{\mathrm{t}}^{*} \text { OPEREXP }_{\mathrm{t}-1}+\beta_{16} \text { Fraud }_{\mathrm{t}}^{*} \text { OPEREXP }_{\mathrm{t}}+\beta_{17} \text { Fraud }_{\mathrm{t}}^{*} \text { OPEREXP }_{\mathrm{t}+1}+ \\
& u_{t}
\end{aligned}
$$

And Panel $C$ presents the different matching between revenues and cost of goods sold for the fraud and non-fraud samples using the following equation:

$$
\begin{aligned}
& \text { Sales }=\delta_{10}+\delta_{11} \text { Fraud }_{\mathrm{t}}+\delta_{12} \text { COGS }_{\mathrm{t}-1}+\delta_{13} \text { COGS }_{\mathrm{t}}+\delta_{14} \text { COGS }_{\mathrm{t}+1}+\delta_{15} \text { Fraud }_{\mathrm{t}}^{*} \text { COGS }_{\mathrm{t}-1}+ \\
& \delta_{16} \text { Fraud }_{t}^{*} \operatorname{COGS}_{\mathrm{t}}+\delta_{17} \text { Fraud }_{\mathrm{t}}^{*} \mathrm{COGS}_{\mathrm{t}+1}+v_{\mathrm{t}} \cdot
\end{aligned}
$$

Two-tailed t-test with t-statistics adjusted for clustering of standard errors by industry and year. ***, **, and $*$ denote significance at the 1 percent, 5 percent, and 10 percent levels, respectively.

See Tables 2 and 5 for variable definitions. 


\section{Conclusion}

Expenses are recognized by applying the matching principle on the basis of a causal relation between expenses incurred and revenue earned. Expenses are also recognized when a decrease of economic benefits, related to a decrease in an asset or an increase of a liability, can be measured reliably. The matching principle should be cautiously applied when we compare between fraud and non-fraud firms, given that fraud firms convey a different recognition of expenses in order to manipulate earnings. This study examines whether the degree of matching for fraud firms is different from that for non-fraud firms depending on the level of a causal relationship between expenses and revenues. Note that fraud firms are known to mask their economic performance to manipulate earnings by mostly using non-operating items. We expect that the degree of matching for fraud firms is different from that for non-fraud firms at the strong level of the causal relation between expenses and revenues, while there is no difference of the matching between fraud and non-fraud firms at the weak causal relation.

Empirical results indicate that the degree of matching for fraud firms is different from that for non-fraud firms when the causal relation is strong (e.g., between cost of goods sold and sales or between operating expenses and sales); however, the degree of the matching for fraud firms does not differ from that for non-fraud firms when the causal relation is weak (e.g., between total expenses and to- tal revenues). This result implies that the different degrees of the matching between expenses and revenues exist at the varying levels of the causal relation between expenses and revenues.

An innovative aspect of this study is that we use actual fraud firms against which the Korean Financial Supervisory Service took enforcement actions. This study contributes to the literature by emphasizing the importance of the level of the causal relation with respect to the matching between expenses and revenues. Thus, when comparing fraud firms to non-fraud firms, investors should pay attention to the causal relation between expenses and revenues.

One limitation of this study is that only a small number of firms are identified as fraud firms although we use actual fraud firms. This is because the Korean Financial Supervisory Service selects only a limited number of firms for enforcement in a year. Another limitation is that the contemporaneous matching between revenues and total expense for the non-fraud sample is not consistent with prior studies. Currently, we think this is due to the sample period that covers several economic crises. A more detailed analysis should be performed in subsequent research. Also, Dichev and Tang's (2008) model is not designed to identify what items causes poor or proper matching at the level of individual items. Future research could be done to identify individual items on financial statements that cause the different matching across fraud and non-fraud firms. 


\section{References}

Albrecht, W. S., C. C. Albrecht, C. O. Albrecht, and M. F. Zimbelman. 2008. Fraud Examination. Mason, Ohio: Thompson-Southwestern.

Altman, E. I. 1968. Financial ratio, discriminant analysis, and the prediction of corporate bankruptcy. The Journal of Finance 23 (4): 589-609.

Beneish, M. D. 1999. The detection of earnings manipulation. Financial Analysts Journal 55(5): 24-36.

Brazel, J. F., K. L. Jones, and M. F. Zimbelman. 2009. Using nonfinancial measures to assess fraud risk. Journal of Accounting Research 47(5): 1135-1166.

Collins, D., E. Maydew, and I. Weiss. 1997. Changes in the value relevance of earnings and book values over the past forty years. Journal of Accounting and Economics 24: 39-67.

Choi, K. and K. Choe. 2003. An analysis of the corporate characteristics of companies reporting aggressive accounting. Korean Accounting Review 28(2): 211-245.

Choi, K. and W. Paek. 1998. Empirical study about the earning manipulation of enforcement firms. Korean Accounting Review 23(2): 133-161.

Dichev, I. and V. Tang. 2008. Matching and the changing properties of accounting earnings over the last 40 years. The Accounting Review 83(6): 1425-1460.

Donelson, D., R. Jennings, and J. McInnis. 2011. Changes over time in the revenue-expense relation: Accounting or economics? The Accounting Review 86(3): 945-974.

Elliott, J., and D. Hanna. 1996. Repeated accounting write-offs and the information content of earnings. Journal of Accounting Research 34(Supplement): 135-155.

Francis, J. and K. Schipper. 1999. Have financial statements lost their relevance? Journal of Accounting Research 37(2): 319-352.

Fan, Y., A. Barua, W. Cready, and W. Thomas. 2010. Managing earnings using classification shifting: Evidence from quarterly special item. The Accounting Review 85 (4): 1303-1323.

Hayn, C. 1995. The information content of losses. Journal of Accounting and Economics 20: 125-153

International Accounting Standards Board (IASB). 2001. Framework for the Preparation and Presentation of Financial Statements.

Kirkos, Efstathios, C. Spathis, and Y. Manolopoulos. 2007. Data mining techniques for the detection of fraudulent financial statements. Expert Systems with Applications 32: 995-1003.

Marquardt, C. A., and C. I. Wiedman. 2004. How are earnings managed? An examination of specific accruals. Contemporary Accounting Research 21: 461-489.

McVay, S. 2006. Earnings management using classification shifting: An examination of core and special items. The Accounting Review 81: 501-531.

Paek, W. 2011a. The change in accounting environment and the matching principle. Korean Management Review 40(1): 29-49.

Paek, W. 2011b. The matching principle and earnings quality. Korean Accounting Review 36(2): 101-127.

Paek, W., and S. Park. 2013. Firm life-cycle stages, revenue-expense matching, and the differential patterns of expense recognition. Korean Accounting Review 38(2): 215-245. 
Gadjah Mada International Journal of Business - May-August, Vol. 16, Na 2, 2014

Park, S., and W. Paek. 2013. The effects of matching principle on incremental value relevance and relative pricing multiples between accounting information. Korean Accounting Review 38(1): 173-208.

Persons, O. S. 1995. Using financial statement data to identify factors associated with fraudulent factors associated with fraudulent financial reporting. Journal of Applied Business Research 11(3): 38-46. 
